International Journal of Linguistics, Literature and Translation

ISSN: 2617-0299 (Online); ISSN: 2708-0099 (Print)

DOI: 10.32996/ijltt

Journal Homepage: www.al-kindipublisher.com/index.php/ijltt

\title{
A Reading of Charles Dickens' Hard Times (1854) As a Crime Novel
}

\author{
Lina Taysir Alzouabi 8 (D) \\ MA in English Literature, Department of English Language and Literature, Al-Zaytoonah University, Amman, Jordan
}

$\triangle$ Corresponding Author: Lina Taysir Alzouabi, E-mail: linazouabi@gmail.com

\begin{abstract}
ARTICLE INFORMATION
Received: March 15, 2021

Accepted: April 22, 2021

Volume: 4

Issue: 4

DOI: $10.32996 / i j \mid l t .2021 .4 .4 .21$

\section{KEYWORDS}

Charles Dickens, Hard Times, Victorian Era, Crime, Crime Novel

\section{ABSTRACT}

This study explores how Charles Dickens presents a panoramic picture of social and moral crimes, criminals, victims and the causes as well as consequences of criminality in his novel Hard Times (1854). By employing Collins' Dickens and Crime (1964), the article provides a reading of Dickens' Hard Times as a crime novel, arguing that this novel is not only a social commentary on England in the Victorian era for the purpose of achieving social reform at the time. It is also a crime novel, portraying different types of crimes with various motives and criminals from different backgrounds and classes. Gradgrind, a follower of the utilitarian philosophy, manipulates his daughter Louisa into marrying the capitalist Bounderby for social and economic benefit, which, as a result, gets her to be exploited by Harthouse. In addition, Gradgrind's philosophy has affected his son Tom who has turned into an idle and selfish person, stealing the bank and indicting Stephen and indirectly causing the latter's death. Stephen is also a victim of the capitalist society and the Divorce Law, as only the rich have been entitled to divorce. By investigating Dickens' Hard Times as a crime novel, the study attempts to provide new insights into reading Dickens' novels at the present time, arguing that they can be reread as crime novels that intriguingly portray crimes, criminals, motives and the dire consequences of crime.
\end{abstract}

\section{Introduction}

During the nineteenth century, England changed dramatically under the influence of the Industrial Revolution which made a turning point in society. The transition from agriculture to mechanization affected all the aspects of life. The increase in the number of population, the growing number of people who moved to cities and their search for employment characterized the life of people in the Victorian society. People lived in overcrowded slums which were in need of sanitation improvement. The poor were oppressed and exploited socially and physically. The 1834 New Poor Law was intended to help the poor, and workhouses were built to provide a relief for them. However, poor people were deprived of their rights and treated badly. Because of poverty, children were forced to work at an early age as chimney sweepers and factory workers and were deprived of receiving education. Besides, prostitution came as a result of destitution and a way of making a living in order to avoid entering the workhouses. Some people became richer and enjoyed extra privileges while others suffered from cruel conditions. In their pursuit to adapt to the new environment and its principles, the upper and middle classes were ready to commit moral and illegal offences. The desire for wealth gave the upper class the authority to victimize others. These changes shaped the life of Victorian people in which slums, workhouses, child labour, prostitution, drinking and poverty were the main factors that fostered crime.

Crime pervaded and the poor committed crimes and offences out of need. It was rampant not only among the poor and working-class, but it spread to the upper and middle classes. Theft, prostitution and moral as well as legal corruption were crimes which most of the Victorian writers tried to criticize. Crimes during the Victorian era were an inescapable dilemma that provoked writers like Thomas Hardy, Henry Mayhew, Elizabeth Gaskell, Charles Dickens and others to write about and analyze their causes and consequences. Crimes were not only restricted to violent actions committed against the law; social crimes drew the public attention and were parts of criminal behavior. Writers, such as Dickens, took into account that social crimes were tied

\begin{tabular}{ll|ll}
$\mathbf{K}$ & C & AL-KINDI CENTER \\
$\mathbf{R}$ & $\mathbf{D}$ & FOR RESEARCH AN &
\end{tabular} R D DEVELOPMENT Your gateway to world-class research

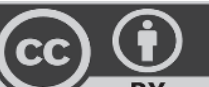

Published by Al-Kindi Center for Research and Development, London, United Kingdom. Copyright (c) the author(s). This open access article is distributed under a Creative Commons Attribution (CC-BY) 4.0 license 
to the environment. Being part of the Victorian society, Dickens suffered the ills of such a corrupt environment and felt responsible for drawing the attention to the need for social reform. Dickens, as a social reformer and a social critic, showed the cruel impacts on the poor people and how poverty forced them into crime. Moreover, Dickens presented the upper classes, contrary to the common misconception, as part of the world of crime. He portrayed various crimes like robbery, murder, child abuse, prostitution and domestic violence which many of his characters were implicated in. Therefore, by investigating Dickens' works, one finds that crime is the main theme, whether it is social or moral.

Charles Dickens is known for portraying the social problems of his time. At the age of twelve, Dickens had to leave school and go to work in a boot blacking factory to support his family when his father could not pay debts. At the age of fifteen, he had to work as a clerk in a law office where he mastered shorthand reports. After that, he worked as a freelance reporter until 1832 when he became a reporter of parliamentary debates. He worked so hard until 1834 when he published his first "sketches" at the age of twenty-one. The socio-economic changes that Dickens witnessed and working in different institutions enabled him to employ his experience in showing the social and moral problems and hence call for reform.

\section{Literature Review}

In his works, Dickens has attacked the defects of the legislative system and the abuses of social and political institutions. Poverty, workhouses, crime, class division, child labour, injustice and the education system have been exposed through his

Writings to emphasize the importance of reform. In Hard Times (1854), Dickens shows the cruel effects of class division, the education system and economical as well as social issues. He provides images of exploitation among different classes for different reasons. Dickens presents a materialistic world in which individuals sacrifice their happiness to follow the values of society. He views two contrasting worlds: the upper class represented by Gradgrind and Bounderby and characters from the lower classes as Stephen Blackpool and Sissy, proving the influence of the environment on people. As a result of such circumstances, crimes like robbery, murder, child abuse and legal offences have pervaded society on different levels. It is worth mentioning that Dickens portrays crimes committed against individuals in many of his novels. In Oliver Twist (1837-1839), he explores the social-ills of the New Poor Law, the underworld of London and the abuse of children. Besides, he presents the character of Monks, an upper class, who turns to be Oliver's half-brother. Monks tries to incriminate Oliver to deprive him of his inheritance out of grudge. Moreover, Dickens portrays the life of Nancy, a prostitute who is forced by poverty and a corrupt environment to live among criminals and be one of them. So by presenting the misery of the Victorian society, Dickens succeeds in highlighting the role of the environment in creating criminals. Moreover, in Great Expectations (1860-1861) Dickens also comments on the problems of his time which reflects the defects of the moral and legal system. Great Expectations is full of images of crime like murder, robbery, child abuse and moral defects. Dickens' "deep social commitment and awareness" of the social ills are "derived from his traumatic childhood experiences when his father was imprisoned in the Marshalsea Debtors' Prison ... and he at the age of twelve worked in a shoe-blacking factory" (Diniejko, 2012). Industrialization and urbanization in a capitalist society are the main concern of Dickens, so he has devoted Hard Times to reflect the conditions of the English society. Lodge (1969) writes:

On every page Hard Times manifests its identity as a polemical work, a critique of mid-Victorian industrial society dominated by materialism, acquisitiveness, and ruthlessly competitive capitalist economics. To Dickens, at the time of writing Hard Times, these things were represented most articulately, persuasively, (and therefore dangerously) by the Utilitarians. (p. 86)

In Hard Times, Dickens has his own reflections on different issues like class division, education and human rights under the influence of Thomas Carlyle's social criticism. Carlyle (1931) has revealed the effects of the materialistic society that denies imagination and emotion, and Dickens has been able to show that "in Hard Times human relationships are contaminated by economics" (Diniejko, 2012). Furthermore, individuals are also evaluated by industrial perceptions such as utilitarianism. Dickens has suggested that living in such an environment deprives individuals of their minds, souls and morals. Schor (2001) argues that Hard Times requires clearly

to be read not as a mere fictional world but as a commentary on a contemporary crisis. It is, after all, Hard Times for These Times, and it is dedicated to Thomas Carlyle, the social thinker whose vision of a society of human connections ... influenced Dickens so profoundly in the 1840s and 1850s. (p. 67)

Most, if not all, Dickens' novels expose moral messages; they are to entertain readers and uncover profound issues that alert readers to what is happening around them. Miller (1958) points out that "each of these three novels [Little Dorrit, Hard Times and A Tale of Two Cities] is concerned with the conflict between two forms of relationship: relation to society, and direct, intimate relation to other individuals" (p. 225). Dickens indicates that Industrialization is the main reason for ruining individual values and the traditional way of life. Dickens believes that there is a relation between materialistic gain and crime. Manufacturers, for example, treat their workers as machines, call them 'Hands' and deprive them of their human dignity. Workers are portrayed as victims of society and thus have to struggle in order to survive. In Hard Times, Dickens highlights this point through the 
conversation between Gradgrind and Bounderby who never know "what they [want]; that they [live] upon the best, and [buy] fresh butter; and [insist] on Mocha coffee, and [reject] all but prime parts of meat, and yet [are] eternally dissatisfied and unmanageable" (Dickens, 2006, p. 21).

By introducing different classes in the novel, Dickens manages to show that crime is not restricted to one class or a certain condition. Around the 1820 s, crime spread as a result of poverty and unemployment, "but this view which suggests that poverty ... is the cause of all crime, was not later accepted as the prime cause of crime" ("The Victorian Age Society and Its Underworld," n. d.). To sum up, the selected novel is an evident criticism of the consequences of the Industrial Revolution and the philosophy of utilitarianism which the society has been based on, as it reflects a world of crime, prison, murder, deception and moral abuse. Dickens extends his depiction by delving deep into the cause of crime, whether it is related to external elements as society and poverty or internal motives as hereditary.

\section{Methodology}

In his novels, Dickens calls for social reform and presents images of corruption in Victorian Britain. Many writers and researchers like Miller (1958) and Pykett (2002) see Dickens as a social reformer and a critic; there were others who have tried to show him as a crime writer. Collins's Dickens and Crime (1964), which this study depends on as a framework, provides an insight into Dickens' creative imagination, thinking and writing about crime. The book presents a revaluation of Dickens' novels depending on the chronological development of the criminal characters. Dickens' novels present crime and harrowing scenes of prison, murder, workhouses, capital punishment and prostitution. Collins develops the themes of his chapters in connection with the progression of Dickens' career and the development of the law. The book gives an illustration of Dickens' treatment of crime through reform and punishment and presents the development of the legislative organizations. What distinguishes this study is its attempt to present the underworld of the Victorian society in Dickens' Hard Times by providing a reading of this novel as a crime novel, as this novel highlight different kinds of crimes committed by characters of different classes.

\section{Results and Discussion}

In Hard Times (1854), Dickens, as a citizen and witness of events during the Victorian period, tries to create a fictional world that represents reality. The novel is divided into three separate books. The first book is "Sowing," the second is "Reaping" and the third book is entitled "Garnering." In the first two books, Dickens demonstrates the biblical notion of "whatsoever a man sowed, that shall he also reap." Dickens exposes crimes committed directly or indirectly and points out how the heartless industrialists and educators collaborate to turn people into machines, depriving them of any vent of emotion, imagination and entertainment. He produces two groups in the same world in order to refer to the defects of the Industrial Revolution and the crimes committed against people. The first group is represented by Bounderby and Gradgrind, capitalists and holders of vicious education of Utilitarian philosophy. The second group is represented by those who refuse to be victims of the first group's stony conventions and theories of logic. Dickens introduces Gradgrind as a "man of realities. A man of fact and calculations" (Dickens, 2006, p. 4). Gradgrind applies a strict method of teaching in which no way for imagination and entertainment can be enjoyed. Unfortunately, this system is also exercised at home as his children are severely raised without any sense of emotion and love.

The title of the second chapter "Murdering the Innocent" is clear evidence of the resulting crimes which are about to come. Gradgrind deals with children as if they were machines, depriving them of their childhood. Dickens presents Gradgrind's home as a workhouse in which children are victims of society. The first crime committed by Gradgrind against his children is when he prevents them of enjoying their lives and forbids any kind of fantasy:

No little Gradgrind had ever seen a face in the moon; it was up in the moon before it could speak distinctly. No little Gradgrind had ever learnt the silly jingle, Twinkle, twinkle, little star; how I wonder what you are! No little Gradgrind had ever known wonder on the subject, each little Gradgrind having at five years old dissected the Great Bear like a Professor Owen, and driven Charles's Wain like a locomotive engine-driver. (pp. 11-12)

One example of a lost childhood is when Tom and Louisa attempt to peek through a hole in a circus tent, which reflects their curiosity as children. However, Gradgrind considers it a violation of his principles and becomes angry. When he asks them why they have done such a deed, his daughter answers: "'I was tired, father. I have been tired a long time,' said Louisa. 'Tired? Of what?' asked the astonished father. 'I don't know of what - of everything, I think'" (p. 15). Dickens believes that the family, the first environment for children, plays a crucial role in forming children's identity and morality. Angela Santoni states that Dickens has "felt that children have certain needs: guidance in nurturing home, to be free from emotional and physical abuse, to have good education, and to be allowed to use their imaginations" (cited in Makati, 2008, p. 135).

Dickens' concern is about the victims of society; Louisa is one of them. Her father wants her to neglect her heart and rely only on mind. Louisa's upbringing deprives her of all the joy of childhood and makes her lose her connection with people; such upbringing causes Louisa's failure in her life and deprives her of any sense of emotion. The first crime against her is her marriage 
to Bounderby. Louisa's response to her father illustrates the harm he causes to her; her opinion reflects the injustice and oppression of the life her father imposes upon her:

'Why, father,' she pursued, 'what a strange question to ask me! The baby preference that even I have heard of as common among children, has never had its innocent resting place in my breast. You have been so careful of me, that I never had a child's heart. You have trained me so well that I never dreamed a child's dream. You have dealt so wisely with me, father, from my cradle to this hour, that I never had a child's belief or a child's fear.' (Dickens, 2006, p. 111)

Louisa's answer is a clear comment on the harm of her father's philosophy in raising them. A close reading of her conversation with her father shows the depression and grief she feels; she misses the role of the heart in her life. Gradgrind proves this when he tells Louisa that: "you are not impulsive, you are not romantic, you are accustomed to view everything from the strong dispassionate ground of reason and calculation" (p.106). According to Lendvoy (1976), "Louisa's disinterest in her own emotional life is a telling enough comment on her condition. Her father's performance as Pandarus suggests Dickens' ironical contempt for the distorted values that justify and even encourage such a marriage" (p. 38).

Gradgrind has been pleased with Louisa's decision to marry Bounderby, yet her approval is considered as a kind of self-sacrifice to please her father, and more precisely, to support her brother, Tom. Lendvoy states that the "particular abuses of marriage are generally related to the parental crimes or crimes against the individual. The sacrifice of Louisa...exemplifies the manipulation of sentiment for economic or social expediency" (p. 38). By presenting a character such as Louisa, Dickens defines the traditional role of women in the Victorian period in which they have been victims of male dominance and parental crimes; moreover, Gradgrind's "ideology and Bounderby's hypocritical self-interest reflect what Dickens felt were the worst abuses of Victorian society" (p. 36). Gradgrind's fruits of his philosophy are about to be reaped. Reason, fact and logic have nothing to do now with a material marriage. Louisa feels something is missing, like her mother who says that "there is something - not an Ology at all that your father has missed, or forgotten, Louisa. I don't know what it is.... It makes me restless" (Dickens, 2006, p. 214). Pykett (2002) in Critical Issues believes that

the awful consequences of this educational philosophy, and its embargo on wonder and fancy, are seen in the blighted life of Louisa Gradgrind, who, after carefully considering the facts of the case (and in order to assist her brother), embarks on a loveless marriage with a man whom she finds repulsive. (p. 141)

Later, Louisa is exploited by James Harthouse, a wealthy and cunning young man who neither believes in the philosophy of fact nor is able of any fancy, as he attempts to seduce Louisa who has not been motivated by such feelings before. Mccarthy (1971) describes Harthouse as "the 'villain' of the piece ... He is possessed of a self-knowledge and understanding which none of Dickens' 'evil' characters have ever revealed before (p. 49). Therefore, Louisa becomes aware of the missing part of her life, her heart. This is a turning point in her character, for she realizes the harm her father has caused her; her rational upbringing destroys her emotional life. She has been deprived of emotional bonds as a sister, daughter and wife due to a brother's, father's and husband's opportunistic relationship in a materialistic world. The novel uncovers the immoral and the lack of spiritual values that have spread out in the Victorian period. Harthouse's exploitation of the innocent and inexperienced Louisa reflects how she has been victimized by relationships of self-interest. Makati (2008) points out that "Louisa is a victim of the constraints of her society because she did not choose her partner because of love, but for economic reasons. The suppression of her sexuality forces her to challenge the moral values of her society (p. 124). As a result of her father's philosophy and wrong upbringing, "Louisa could not have contemplated marriage to such a creature as Bounderby unless her natural desires had been buried under layers of her father's fact" (Lendvoy, 1976, p. 34). Therefore, when she leaves her home to her father's estate, instead of eloping with Harthouse, Louisa renders the crime committed against her as a product of a destructive philosophy and corruptive society. So as a child, Louisa is victimized by her father who is considered as a criminal for abusing and destroying his daughter's life. Her conversation with her father illustrates this point:

I curse the hour in which I was born to such a destiny.... How could you give me life, and take from me all the inappreciable things that raise it from the state of conscious death? Where are the graces of my soul? Where are the sentiments of my heart? What have you done, $O$ father, what have you done, with the garden that should have bloomed once, in this great wilderness here! (Dickens, 2006, p. 231)

Gradgrind's advocacy of his philosophy suffocates the whole family. Tom is another example of a victimized child; the poison of the Industrial Revolution pollutes his morals and turns him into a criminal. Tom's childhood turns him into a machine without imagination, emotion and moral values; he says: "'I am sick of my life, Loo. I, hate it altogether, and I hate everybody except you,' said the unnatural young Thomas Gradgrind in the hair-cutting chamber at twilight" (p. 55). As a result, "the consequences of Gradgrindery are seen, too, in the calculating self-interest of Louisa's brother Tom" (Pykett, 2002, p. 141). When Tom becomes an adult, he is known for his idleness at work, debts, and selfishness shown by exploiting his sister and her marriage to get rid of her father's control. Tom is a reflection of repressed desires; therefore, to achieve his goals, he encourages his sister to accept Bounderby's proposal. The consequences of the Utilitarian education and wrong upbringing manifest themselves in Tom's 
exploitation of his sister and brother-in-law to gain his material benefits. He knows that his sister will not let him alone, so by convincing her to marry Bounderby, he becomes another accomplice in the crime against Louisa's life:

'I persuaded her,' he said, with an edifying air of superiority. 'I was stuck into old Bounderby's bank (where I never wanted to be), and I knew I should get into scrapes there if she put old Bounderby's pipe out; so I told her my wishes, and she came into them. She would do anything for me....because my liberty and comfort, and perhaps my getting on, depended on it; and she had no other lover, and staying at home was like staying in jail - especially when I was gone. (Dickens, 2006, p. 147)

In his description of Tom, Dickens does not blame him together for what he becomes. He devotes a full chapter titled "The Whelp" to describe "a young gentleman who had been brought up under one continuous system of unnatural restraint" (p. 144) and to show the role of society in creating criminals as Tom. Mccarthy (1971) illustrates that "Dickens may state that man's environment determines his character, but it is evident that his characters have 'given' moral natures which are only affected temporarily by their surroundings, if they are affected at all" (p. 2). Evidently, "it was altogether unaccountable that a young gentleman whose imagination had been strangled in his cradle, should be still inconvenienced by its ghost in the form of grovelling sensualities; but such a monster, beyond all doubt, was Tom" (Dickens, 2006, p. 144). The education that Tom has received gives him an excuse to use and abuse others in order to advance his interests. The supposed crime of his father turns him into a lifeless and exhausted obstinate young man who has rebellious motifs against his father's education and plans to take revenge: "when I [Tom] go to live with old Bounderby, I'll have my revenge. I mean, I'll enjoy myself a little and go about and see something, and hear something. I'll recompense myself for the way in which I have been brought up" (p. 57). The roots of criminality inside Tom start to bloom since childhood; his destructive tendencies are demonstrated in his conversation with Louisa: "I wish I could collect all the Facts we hear so much about ... and all the Figures, and all the people who found them outand I wish I could put a thousand barrels of gunpowder under them and blow them up together" ( p. 57). So, Tom, as a child, is brought up under a hard philosophy that forms his aggressive inhumane identity. Mccarthy (1971) demonstrates that

turning to Hard Times one can see perhaps an even more scathing attack on those Victorian values which frustrate and destroy the young consciousness ... the novel is focused, thematically and structurally, on those destructive ideologies which threaten the freedom and identity of the young. (p. 33)

The reaping level of Gradgrind's destructive philosophy for Tom reaches its most when Tom plans to steal the bank and indict Stephen Blackpool, a poor worker in Bounderby's factory. Stephen has been told by Tom to loiter outside the bank at night before he leaves the city so that he makes him the first suspect of the robbery. Tom tells him:

when you leave work of a night, between this and your being away, just hang about the Bank an hour or so, will you?

Don't take on, as if you meant anything, if he should see you hanging about there; because I shan't put him up to speak to you, unless I find I can do you the service I want to do you. (Dickens, 2006, p. 174)

Tom manages to rob the bank and pay his debts of gambling. The accusation now is against Stephen who has been dismissed by Bounderby after refusing to spy on his co-workers. Louisa suspects that her brother is the robber; however, he insists on denying these accusations. Finally, he admits his robbery and is smuggled out the country to avoid punishment. Tom's crime has not finished at this point; the death of Stephen is a result of his crime. On his way back to clear his name, Stephen falls in a deserted mine, so Tom's self-interest prevents him from thinking of others. He does not hesitate to make use of others to save and serve himself.

One can see that the predominant theory of Utilitarianism and the inhumane principles during the Victorian period have ultimately destroyed and caused agony to people at that time. Dickens criticizes the reliance on facts and negligence of emotion and fancy, which changes people into mechanized human beings, breaks down relationships and distorts moral values. Dickens wants to prove that the environment shapes and influences the human nature. He gives an example of how the mechanized world turns people into machines. Workers are devastated by poverty and work all the time. Spector (1984) states that

Dickens' naturalism illustrates how the industrial machine demeans men, women and children, subjecting them to abject poverty, anguish and injustice....that men must be like their environment, the workers should be like the most striking and visible aspect of their lives, the machines. (p. 372)

Moreover, Dickens refutes the claim that criminality is attached to the poor and working classes in the novel; for example, Stephen and Sissy exemplify good morals and good natures despite their poverty and need, whereas Bounderby, Harthouse and Tom who belong to the upper class, commit different types of crimes throughout the novel. Harthouse is a young politician who comes from a rich family. He takes advantage of Louisa's miserable life, manipulates her heart and seduces her, besides exploiting her brother Tom and asking him personal information about Louisa's marriage. Harthouse brings plight to Louisa's life by awaking her buried feeling and destroying her marriage, and thus Louisa violates the moral and social norms. Louisa spends the rest of her life unmarried and childless as a result of moral crimes committed against her by her father, her brother and 
Harthouse; all are from the rich class. Bounderby is a man whose world revolves around gains without moral considerations; he is "a man who is boastful, self-centred, completely devoid of affectionate feelings and understanding for others, and overall a very unpleasant person to be around for most Coketowners" (Jönsson, 2009, p. 16). He makes everybody believe that he has worked hard to gain his wealth and proclaims that his mother has abandoned him, saying: "I hadn't a shoe to my foot. As to a stocking, I didn't know such a thing by name. I passed the day in a ditch, and the night in a pigsty. That's the way I spent my tenth birthday" (Dickens, 2006, p. 18). In the end, it turns out that he has a decent family and good education, and he is the one who has abandoned his mother. Dickens portrays him as a hypocrite as well as the vain and self-interested man who is willing to sacrifice anything to save his position. Eventually, Bounderby ends in the same way as his mother ends, in poverty.

Stephen is presented as a victim of his society; through him, Dickens wants to show "the imbalance of power and social classes" (Abuzahra \& Imraish, 2017, p. 25). Stephen is portrayed as "a good power-loom weaver, and a man of perfect integrity" (Dickens, 2006, p. 71). Stephen has been subjected to different levels of prejudice. He is a victim of the Divorce Law, which Dickens considers as a crime "committed against individual freedoms perpetrated by social agents fulfilling roles that have been legitimized by the prevailing conventions and values" (Lendvoy, 1976, p. 43), for only those who have money, are entitled to getting divorced. When Stephen asks Bounderby to divorce his wife, Bounderby tells him that "it costs money. It costs a mint of money" (Dickens, 2006, p. 82). Stephen, here, is victimized by the law in which the poor has no right to free themselves from these obligations. So, getting a divorce depends on money, which clearly proves the corruption of the legislations in the Victorian period. Brown (1977) states that "all social relations, including marriage, and friendship, are mediated through an economic frame of reference" (p. 46).

Stephen is a victim of the law and a capitalist system that uses him to the most from both the workers represented by the Trade Union and the masters. In this novel, Dickens argues that the "industrial society is seen as an oppressive and alienating system, external and hostile to the individuals within it, who function in themselves and through their relations with others as objects, machines, or things" (p. 41). Stephen refuses to join the union on the basis that all unions "contain within them the germs and the elements of crime, they are all founded on the right of the majority to coerce the minority, on the absolute subjugation of the one to the many" (p. 9). His fellow-workers desert him and treat him as an outcast. Moreover, Bounderby dismisses him for refusing to spy on his fellow-workers, and as a result he leaves the city. So, "due to his failure to either join capitalism or fight industrialization, Stephen is defeated by the society in which he lives" (Makati, 2008, p. 86). Tom also exploits Stephen and implicates him in a crime. Tom tells him: "when you leave work of a night ... just hang about the Bank an hour or so" (Dickens, 2006, p. 174). Stephen falls a victim of a treachery crime; he is accused of a crime that he has not committed. He comes back to clear his name and on his way home, he accidentally falls in an old mine, leading to his death. So, Tom's crime has not ended in robbery, but is causing the murder of an innocent person. Crimes committed against Stephen describe the surrounding environment where the poor are denied their rights. Louisa states that even Stephen's fellow-workers have betrayed him to fulfill their demands: "being rejected by one employer, he would probably be rejected by all?" (p. 172). Rachael also blames Bounderby for Stephen's death; "the masters against him on one hand, the men against him on the other" (p. 269).

In Hard Times, we can see how acquiring material advantages overcomes human values and feelings. Brown (1977) declares that "the mature novels [the novels of the 1850's and 60's] repeatedly identify the spread of an inhuman and degrading business or money ethos into all areas of social life, a pervasive spread of moral corruption located in the new economic realities of midVictorian England" (p. 50). All in all, the exploitation of children, workers and family relationships is prominent in the novel in which several types of crimes are committed by people from different classes and with different motives.

\section{Conclusion}

During his life, especially as a child, Dickens has suffered harsh socio-economic changes; therefore, he has portrayed Victorian society with its flaws and defects in his writings. He has written about the plight of the poor, the defects of the legislative system, the system of education and moral deterioration. The Industrial Revolution has produced an ill-environment in which crimes have been rampant. Dickens portrays the world of crime, its causes and motives and suggests solutions for preventing crime. The theme of criminality appears in most of his works and reveals the secrets of the underworld of the Victorian society. The common misunderstanding that crimes are bred in the lower and poor classes is rebutted. Dickens demonstrates that the New Poor Law of 1834 was meant to reduce the poor's suffering; however, he shows that the system has its defects that aggravate the poor's misery. Poverty, child abuse, prostitution, a strict educational system and crime are the result of such a prejudiced legal system.

In his novel Hard Times, Dickens criticizes the capitalistic society which denies the poor their rights, pointing out how society built on a Utilitarian philosophy destroys people's morals and leads to the world of crime. Class division in Hard Times is treated as the main cause of corrupting individuals' morality, and two contrasting classes are revealed to illustrate the effects of the environment. Whereas some characters are made victims, such as Stephen Blackpool, others are criminalized by the law and 
traditional values of society. Louisa and Tom, who are victims of their father's philosophy of teaching, are forced to break the law and traditional concepts which have been considered as a crime according to the Victorian society's principles. Furthermore, Bounderby, a member of the upper class, commits moral crimes against his workers. He also victimizes a poor worker, Stephen, by depriving him of his rights. Through the story of Stephen, Dickens sheds light on the injustice of the law, especially the Divorce Law, which gives the right to divorce to the upper classes and deprives the poor of it.

Dickens Hard Times can evidently be read as a crime novel, as it presents different types of crimes in the Victorian society, illustrating the causes and motives behind crimes. In the novel, Dickens also contradicts the traditional belief that crimes are caused only by the poor and provides his analysis with examples of upper classes, which supports his vision that crimes are the offspring of the ill-environment. The analysis of the selected novel makes it clear that the deformed law, corrupted socioeconomic system, strict educational system and immoral relationships have been factors in creating criminals in the Victorian era. By reading one piece by Dickens at the present time, the study has attempted to provide new insights into one canonical text by Dickens, arguing that Dickens' novels can be reread as crime novels that intriguingly portray crimes, criminals, motives and the consequences of crime. So, future studies can comparatively read more than one work by Dickens to illustrate the points investigated in the present study further.

Funding: This research received no external funding.

Acknowledgments: I would like to express my deep gratitude to my family and friends who have taught me that nothing is impossible. I would also like to thank my supervisor Professor Taher Badinjki for his useful comments and remarks throughout the MA program. Special thanks go to the Department of English Language and Literature at Al-Zaytoonah University, Amman, Jordan.

Conflicts of Interest: The author declares no conflict of interest.

\section{References}

[1] Abuzahra, N. \& Imraish, N. (2017). The industrial revolution impact on families as seen in Hard Times. Studies in Linguistics and Literature, 1(1), 23-28.

[2] Brown, J. M. (1977). A sociological analysis of the novels of Charles Dickens. [Unpublished doctoral dissertation]. The London School of Economics and Political Science. Retrieved from hetheses.Ise.ac.uk.

[3] Carlyle, T. (1931). Past and present. J. M. Dent \& Sons.

[4] Collins, P. A. (1964). Dickens and crime. Macmillan, St Martin's Press.

[5] Dickens, C. (1994). Oliver Twist. York Press.

[6] Dickens, C. (2002). Great expectations. Penguin.

[7] Dickens, C. (2006). Hard Times. (Webster's German Thesaurus Edition). ICON Group International.

[8] Diniejko, A. (2012). Charles Dickens as social commentator and critic. Retrieved from The Victorian Web.

[9] Jönsson, A. (2009). The importance of time in Charles Dickens' Hard Times. Retrieved from urn.kb.se.

[10] Lendvoy, L. (1976). Social criticism in English novel; Dickens to Lawrence. [Unpublished master's thesis]. University of British Columbia.

[11] Lodge, D. (1969). The rhetoric of Hard Times. In E. Gray (Ed.), Twentieth century interpretations of Hard Times. A collection of critical essays. Prentice-Hall.

[12] Makati, P. (2008). A critical study of Charles Dickens' presentation of the socially disadvantaged. [Unpublished master's thesis]. University of Fort Hare (East London Campus).

[13] Mccarthy, C. (1971). The social criticism of Charles Dickens: A point of view. [Unpublished master's thesis]. McMaster University,Hamilton, Ontario.

[14] Miller, H. J. (1958). Charles Dickens: The world of his novels. Harvard University Press.

[15] Pykett, L. (2002). Critical issues: Charles Dickens. Palgrave.

[16] Schor, H. (2001). Novels of the 1850s: Hard Times, Little Dorrit, and A Tale of Two Cities. In J. O. Jordan (Ed.), The Cambridge companion to Charles Dickens (pp. 64-77). Cambridge University Press.

[17] Spector, S, J. (1984). Monsters of metonymy: Hard Times and knowing the working class." ELH, 51(2), 365-384.

[18] The Victorian age society and its underworld. (n. d.). Retrieved from shodhganga.inflibnet.ac.in. 